\title{
New Life’s Pilgrim in How I Finally Lost My Heart
}

\author{
WANG Li-ping \\ Shanghai Institute of Technology, Shanghai, China
}

\begin{abstract}
The process of women' growing up and getting rid of traditional female life plays an important role in many Doris Lessing's works. This paper focuses on analyzing how the heroin shrugs off the bondage of traditional woman and gets her new life in Doris Lessing’s short story How I Finally Lost My Heart.
\end{abstract}

Keywords: tradition, new life, freedom, heart

\section{Introduction}

Doris Lessing, a distinguished British female writer, won the 2007 Nobel Prize in literature. As a prolific writer, Lessing has been regarded as one of the most important postwar writers in English and an insightful prophet of her times. The Swedish Academy described her as "that epicist of the female experience, who with skepticism, fire and visionary power has subjected a divided civilization to scrutiny” (Wikipedia). Varied in writing style and concerned many different themes in her works, she is particularly skilled in capturing the atmosphere and sights of Africa, in describing the struggles of independent women and in measuring the gap between the old and young generations in modern times. Many of her female characters search for ways to do meaningful work and they strive to redefine themselves in a rapidly changing world. "Lessing is particularly concerned about women's growth, self-understanding and the ultimate freedom” (MA, 2005, p. 30).

In the short story How I Finally Lost My Heart, Doris Lessing narrated in detail the heroine's pilgrim to new life. Though the process of the heroine's last decision is full of hesitation for her abusing self-awareness, she won herself and lost her heart (traditional and secular one) and gained freedom both physically and mentally.

\section{Misleading of Traditional Idea Toward Female and Misunderstanding of Loneliness}

Experienced two failed marriages, the heroine in How I Finally Lost My Heart was heartbroken and painful, especially when she lost her first lover. "When he left me for new pastures, I spent two years, or was it three, half dead, and my heart was a stone, impossible to carry about, considering all the other things weighting on one” (Lessing, 1996, p. 591). But why did she still want to look for her Mr. C? Why did she fail her marriage one after another? Reading over the story, we will find that the heroine's misunderstanding of loneliness and misleading of traditional idea about woman lead her to painful life.

Traditionally, a woman is subjected to both social decrees and men, having no mind of her own. Aristotle once said that: The male is by nature superior, and the female inferior; and the one rules and the other is ruled. This was a voice from more than 2300 years ago. Another thing equally old is that we have been told that Eve is

WANG Li-ping, assistant, M.A., School of Foreign Languages, Shanghai Institute of Technology, Shanghai, China. 
only a bone of Adam. We can well infer from these two sayings how long the history of women suppression has been. The masculine has become to be widely identified as active, dominating, adventurous, rational, and creative; the feminine, by systematic opposition to such traits, has become to be identified as passive, acquiescent, timid, emotional, and conventional.

The heroine in the story kept these traditional ideas in mind deeply. She confirmed that woman must depend on man and cannot live alone in the society and the best way of relying on the man is to marry him. "But there is no way of getting over this difficulty, for a serious love is the most important business in life, or nearly so. At any rate, most of us are engaged in looking for it” (Lessing, 1996, p. 591). Given up female's identity in society, the heroine chose a hard way to look for her "serious love", to look for her third and even thirteenth lover. On the excuse of searching for true love, she tore her heart again and again, which made her to be the victim of traditional idea.

Besides, the heroine did not understand herself in the right way. With no idea of knowing the things she really needed and having no right awareness of single life, she was afraid of loneliness. She ignored the reason for her failed marriage was her ignorance of lonely heart which no one can help her. She felt imprisoned and entrapped by the suffocating private realm that seems to deny her a communal life of sharing and caring. Only when she reaches the public space can she liberate herself from the pressure of loneliness, though the cost is a confrontation with heartbroken end. She thought she could walk away from this predicament by her so-called life partner. But fact speaks louder than words, she was wrong. What can help her to be away from loneliness is to find the voice of her own, not simply to follow the herd, not to change her love partner from Mr. A to Mr. C, one after another. So, she confused in the word of misleading and her own misunderstanding.

\section{The Awareness of the Soul}

After tore by painful experiences, the heroine placed great hopes on Mr. C., But she gave up at last. Her awareness of herself and her heart stopped her to take stupid action as she did before. She cut down the road toward "happiness life" with Mr. C when she looked forward to their following life. The heroine became an attractive and ripe woman, "I saw myself quite plainly in a moment of truth: I was standing at a window (on the third floor) with A and B (to mention only the mountain peaks of my emotional experience) behind me, a rather attractive woman...There I stood, brushed dressed, red-lipped, kohl-eyed, all waiting for an evening with a possible C" and Mr. C also was the heroine's "ideal” lover from appearance. "And at another window overlooking (I think I am right in saying) Margaret Street, stood C, brushed, washed, shaved, smiling: an attractive man (I think)...” (Lessing, 1996, p. 592-593). She smiled for they were matched for each other at appearance. While she recognized that Mr. C may be a person who also needed to be saved.

We both held our hearts in our hands, all pink and palpitating and ready for pleasure and pain, and we were about to throw these hearts in each other's face like snowballs, or cricket balls (How's that?) or, more accurately, like great bleeding wounds: "Take my wound. Because the last thing one ever thinks at such moments is that he (or she) will say: Take my wound, please remove the spear from my side. No. not at all; one simply expects t get rid of one's own. (Lessing, 1996, p. 593)

She realized she could not rely her whole life on others and her happiness could not be on others' hands.

Many of Doris Lessing's works show the new image of women, as Shirley Budros said "the woman who 
chooses a career instead of marriage occasionally appears in Lessing's stories” (Shirley Budros, p. 97). How I Finally Lost My Heart is another Lessing's work to call for that the marriage is not the only way to happiness. It is not an easy thing for the story's heroine to get her psychological reorganization. She always held her heart on her hand getting ready to show it to her serious love. When she put down the telephone which she was ready to call Mr. C, she did not understand the root of her former tragedy marriages totally. She just felt the common among Mr. C, Mr. B, and Mr. A, but vaguely. So she did not feel easy at first. "To get something one wants simply by accident—no, there's no pleasure in it, no feeling of achievement” (Lessing, 1996, p. 593). However, she began to think about her life by herself, not following other's idea and traditional thought. The psychological awareness is an important turning point for the heroine's fate.

\section{Refreshed by an Unexpected "Mirror"}

The heroine had psychological awareness, but how to put herself in a right position or how to deal with her heart which she held her hand confused her. She knew that the feeling was not something like stone which could throw out freely. "If this were a stone in my hand, a stone, I could throw it over a tree ....” (Lessing, 1996, p. 592). She was lost in contemplation until she met a "mirror"- - a madwoman on the train.

The madwoman was just like a mirror for her, she saw herself from the madwoman's image. On the other side of the compartment, about eight persons away, sat a youngish woman, wearing a cheap green cloth coat, gloveless hands, flat brown shoes, and lisle stockings. She must be rather poor-a woman dressed like this is a rare sight, these days. (Lessing, 1996, p. 596). That image is far from appreciation. Actually, it is ugly and miserable, which is useless in every aspect. "Look what I've got, I don't care about you and your cigarette case, I've got a silver heart”. "Hear that sound? That's laughter, yes. That's me laughing, yes, that's me” (Lessing, 1996, p. 598). At this moment, the heroine's heart seemed enlightened suddenly. She found the similarity between the madwoman and herself, though they showed it in different ways (one through disgusting appearance, the other through pain insight world). Both heroine and the madwoman relieved from their terrible past life and they eventually gained relief and free both physically and emotionally.

\section{Conclusion}

The failures of marriage made the heroine recognize herself little by little. From a woman who kept traditional ideas and rules in mind, then to realize her psychological awareness, and be reborn at last, the heroine won herself. She lost her raw, bleeding, and fresh heart which represented her past life and won her new life which was full of freedom and no man could upset her life anymore. Though the process of heroine's new life pilgrim was full of frustration and suffering, she challenged herself, even challenged attitude which almost held by all women and men toward women. She struggled, and she won.

\section{References}

Budros, Shirley. (1987). “'Free Women’: The Irony of Escape,” the theme of Enclosure in Selected Works of Doris Lessing, New

York: the Whitson Publishing Company. p. 97

Doris Lessing. In Wikipedia. Retrieved from https://en.wikipedia.org/wiki/Doris_Lessing

Lessing, D. (1996). How I finally lost my heart (5th ed.). In P. A. Smith et al. (Eds.), The heath introduction to fiction (pp. 590-598).

Lexington, D.C.: Heath and Company.

MA, A. H. (2005). The art in How I Finally Lost My Heart by Doris Lessing. Foreign Languages and Their Teaching, $2,30-32$. 